\title{
Pengolahan Sumber Daya Air untuk Meningkatkan Kesejahteraan Masyarakat di Desa Karangrejo Dusun Gutean Kecamatan Purwosari Kabupaten Pasuruan
}

\author{
Mochamad Mas'ud, Rukma Nur Patriya, Januar Sasongko \\ 1) Fakultas Mesin, Universitas Yudharta Pasuruan, \\ 2) Fakultas Sipil, Universitas Yudharta Pasuruan \\ 3) Fakultas Sipil, Universitas Yudharta Pasuruan \\ masud89@gmail.com
}

\begin{abstract}
Abstrak:
Program IbM ini bertujuan untuk. membentuk masyarakat mandiri dan sadar lingkungan dalam mengelolah sumber daya air, Meningkatkan kesejahteran masyarakat dalam pembangunan desa, menciptakan teknologi sistem pengolahan air pipanisasi, meningkatkan pengetahuan dan kemampuan kelompok mitra dalam mengelolah penerapan manejemen pengolahan air, meningkatkan kepedulian kelompok tani dan masyarakat dalam berkehidupan yang sehat, bersih dan aman. Target dalam program IbM ini antara lain . (1) setiap anggota kelompok tani dan posdaya Al-Huda mampu mengolah kebutuhan air, dimana output dari kegiatan ini bermanfaat bagi keperluan masyrakat sosial, keperluan kebutuhan pokok air keluarga (mandi,cuci dan air minum) dan kegiatan usaha komersial. Adanya manajemen pongolahan air bagi masyarakat yang ternaungi oleh POSDAYA untuk keperluan rumah tangga sehingga mengurangi kecemburuan sosial dalam kebutuhan air tiap keluarga.(2) Meningkatkan kesadaran masyarakat dalam mengelolah air. (3) menciptakan kerjasama atau kemitraan antara pengurus dengan masyarakat sehingga terbentuk komunikasi yang efektif-sehingga program kerja bisa berjalan dengan baik. (4) terbentuknya kehidupan masyarakat yang sehat, bersih dan aman sebagai wujud telah tercapainya kebutuhan air dan kelestarian lingkungan. Metode pendekatan yang dipakai dalam kegiatan ini adalah : (1) Memberikan pelatihan pengolahan manajemen air dalam mendistribusikan keperluan air tiap keluarga, (2) Membuat serta pendampingan pembuatan penampungan dan distribusi air dengan pipanisasi bersama-sama dengan kelompok tani dan masyarakat sebagai anggota posdaya, (3) penyuluhan pentingnya pola hidup sehat, (4) Pendampingan dan pembinaan terhadap masyarakat terhadap penerapan pola hidup sehat, (5) Pelatihan leadership (kepemimpinan) bagi pengurus, (6) Pendampingan dan pembinaan terhadap proses pembentukan pipanisasi air, (7) Pembuatan distribusi pipanisasi air bersama-sama dengan seluruh anggota kelompok tani dan posdaya (masyarakat)..
\end{abstract}

Kata Kunci: pengolahan, pendampingan, kelompok posdaya, pipanisasi, air

\section{PENDAHULUAN}

\section{Analisa Situasi}

Dusun Gutean masuk wilayah desa Karangrejo Kecamatan Purwosari Kabupaten Pasuruan. Wilayah desa Karangrejo terletak $7 \mathrm{~km}$ dari kecamatan Purwosari. Luas desa Karangrejo adalah $304 \mathrm{Ha}$ yang terdiri dari jumlah penduduk 5.780 jiwa dengan 
perincian 2.883 laki- laki, 2.897 perempuan. Desa ini memiliki 3 dusun diantaranya dusun Krajan,dusun Gutean dan dusun Karangtengah. Usaha hasil produk diantaranya berupa kain pel, lap makan, keset tenun, tikar lipat tenun, taplak meja dan sumbu kompor. Letak geografis memiliki ketinggian $508 \mathrm{~m}$ dari permukaan air laut dan curah hujan rata-rata $20-3.0 \mathrm{~mm} /$ th serta suhu rata-rata $50^{\circ} \mathrm{C}$.

Mata pencaharian penduduk dusun Gutean paling besar sebagai petani pemilik, petani penggarap, buruh tani dan usaha keset. Tingkat pendidikan rata- rata tingkat SD 85\%, tingkat SMP dan SMA 14,5\% sisanya tingkat perguruan tinggi 0,5\%. Letak geografis dusun Gutean merupakan pegunungan berkelok menanjak dan beraspal menunjukkan bahwa jalur transportasi ke arah desa ini cukup bagus. Pemandangan penggunungan dan area pertanian tanaman pegunungan menambah asik perjalan ke desa ini. Alat transportasipun bisa ditempuh dengan kendaraan pribadi ataupun kendaraan umum yang beroperasi 24 jam. Sarana prasarana ini mempermudah masyarakat untuk mengakses informasi, teknologi, maupun pengembangan jaringan usaha.

Kondisi geografis sangat mendukung masyarakat untuk mengakses kebutuhan air. Hal ini membuktikan bahwa sumber air di dusun Gutean merupakan sumber air terbesar di daerah desa kerangrejo. Dari salah satu dusun yaitu dusun krajan mengambil sumber air di dusun Gutean. Hal ini menjadi sangat ironis dan prihatin, karena dusun getean untuk mendapatkan air ke rumah-rumah warga 3 hari sekali baru dapat air pada tiap rumah. Kondisi untuk mendapatkan air di dusun Gutean berjumlah 600 KK (kartu Keluarga) atau per rumah yang terdiri dari $350 \mathrm{KK}$ mendapatkan dari sumber Bor (pompa hidram), 50 KK mendapatkan dari swadaya sendiri, dan $200 \mathrm{KK}$ menggunakan pompa air.

Dari $200 \mathrm{KK}$ inilah sumber air yang terdapat di dusun Gutean disalurkan ke tendon air kemudian di distribusikan ke dusun Krajan $\pm 70 \%$ dan 30\% ke dusun Gutean. Distribusi air yang memakai pada dusun Gutean yaitu RT 03 RW02 95 KK, RT 04 RW 0295 KK dan RT 06 RW02 $10 \mathrm{KK}$. Gambaran kondisi umum tentang saluran distribusi dari sumber ke tendon sampai rumah warga yaitu :

Sumber air berukuran panjang $5 \mathrm{~m}$ dan lebar $5 \mathrm{~m}$ dengan kedalam $95 \mathrm{~m}$ (kondisi sumber diatas tandon) Sumber air menuju Tandon berjarak 1,2 km yaitu 20 m pipa berukuran 3", $20 \mathrm{~m}$ pipa berukuran 21/2", $20 \mathrm{~m}$ pipa berukuran 2", dan $800 \mathrm{~m}$ pipa berukuran 11/4", $144 \mathrm{~m}$ pipa berukuran 1". Dari Tandon pipa berukuran 3/4" sepanjang 100 
m dan $1 / 2 "$ sepanjamg $100 \mathrm{~m}$ menuju Tandon milik masjid.

Pada keadaan inilah yang menjadi permasalah warga untuk mendapatkan air untuk keperluan memasak air, mandi, buang air besar dan kecil, wudhu dan usaha. Warga mendapatkan air 2-3 hari sekali permasalah ini karena :

1. Kondisi pipa dari sumber ke tendon banyak yang bocor, maka akan terjadi kehilangan debit distribusi air menuju ke tendon berkurang. (terkena pacul warga pada saat ke ladang) karena posisi pipa tidak tertata.

2. Pipa dari Tandon ke warga khususnya sambungan pipa banyak yang bocor.

3. Tidak ada yang mengelolah air

(diserahkan sepenuhnya oleh desa) akhirnya kesadaran masyarakat masalah air kurang diperhatikan.

4. Tidak adanya pembagian yang merata dari penggunaan tandon yang ada, sehingga kebutuhan di dusun Gutean atas air tidak terpenuhi.

\section{Berdasarkan Undang-undang}

No.7 tahun 2004 tentang Sumber daya air, khususnya pasal 40 tentang jaminan ketersediaan kebutuhan air bersih yang keberadaannya diperlukan dan diutamakan bagi pemenuhan kebutuhan air rumah tangga, maka diperlukan suatu evaluasi untuk mengetahui kekurangan dari sistem tersebut. Agar system penyediaan air bersih di dusun Gutean desa Karangrejo dapat terus berlanjut dan berjalan dengan baik, maka diperlukan evaluasi pada system penyediaan air bersih dilingkungan dusun Gutean. Spesifikasi Tandon untuk penampung air terbuat dari bangunan permanen panjang 4,5 m, lebar 4,5 m dengan tinggi $2 \mathrm{~m}$, tetapi di sebagian dalam tendon tersebut di buatkan tandon khusus warga dusun Gutean pada 200 KK ukuran panjang $1,70 \mathrm{~m}$, lebar $2 \mathrm{~m}$ dan tinggi $1,70 \mathrm{~m}$, dengan kapasitas Tangki $5,78 \mathrm{~m}^{3}$. Jarak Tandon ke rumah warga terjauh sekitar $2 \mathrm{~km}$, kondisi jarak rumah dengan rumah yang lainnya ada yang dekat dan ada yang jauh.

Oleh karena itu perlu penataan kembali atau revitalisasi pemipaan distribusi air baik secara teknis bangunan jaringan maupun kesadaran masyarakat untuk kepentingan kebutuhan bahan pokok khususnya air. Dengan memanfaatkan kelompok Posdaya masjid dan kelompok tani yang selama ini tidak dimanfaatkan fungsi masjid sebagai pusat kegiatan masyarakat. Hal ini dikarenakan kesadaran masyarakat tentang manfaat air serta pengolahaannya masih kurang.

Volume 1, Number 1, Mei 2017| 3 
IbM (Ipteks Bagi Masyarakat) bagi kelompok tani ini memiliki tujuan sebagai berikut.

1. Membentuk masyarakat mandiri dan sadar lingkungan

2. Meningkatkan pengetahuan dan kemampuan kelompok mitra dalam pengolahan air

3. Meningkatkan kelompok tani dan masyarakat dalam berkehidupan yang sehat, bersih dan aman

4. Meningkatkan partisipasi masyarakat dalam pengetahuan jaringan distribusi air

\section{Rumusan Masalah}

Dari hasil diskusi dengan mitra kelompok tani air dan aparat desa, disepakati bersama bahwa yang menjadi permasalahan utama di lingkungan mereka adalah.

a. Bagaimanakah membuat masyarakat sadar akan hidup sehat dan bersih

b. Bagaimanakah cara mengolah air yang lebih bermanfaat bagi kehidupan masyarakat maupun anggota kelompok Diperlukan jaringan pipanisasi air / distribusi air untuk revitalisasi karena keterbatasan modal kelompok tani dan masyarakat

c. Bagaimanakah pengurus kelompok mitra bisa mengelola organisasinya agar berjalan kondusif.

\section{TARGET DAN LUARAN}

Berdasarkan analisa situasi, permasalahan yang telah diuraikan target luaran dari kegiatan IbM bagi masyarakat dusun Gutean desa Karangrejo ini adalah :

1) Adanya kelancaran air bagi masyarakat yang ternaungi oleh kelompok tani dalam memenuhi kebutuhan pokok dan usaha untuk kesejahteraan keluarga khususnya di RT.03, RT.04 dan RT.06 dusun Gutean.

\section{(PRODUK)}

2) Adanya kelancaran air bagi masyarakat yang ternaungi oleh POSDAYA untuk keperluan kegiatan masjid. 


\section{(PRODUK)}

3) Setiap anggota kelompok tani mampu mengelola administrasi pipanisasi air, dimana output dari kegiatan ini bermanfaat untuk meningkatkan kualitas SDM serta mandiri bagi kelompok tani dan kesejahteraan keluarga.

\section{(JASA)}

4) Menciptakan kerjasama atau kemitraan antara pengurus dengan masyarakat sehingga terbentuk komunikasi yang efektif sehingga program kerja bisa berjalan dengan baik.

5) Terbentuknya jaringan pipanisasi air yang bagus sehingga kehidupan masyarakat yang tertib, nyaman dan aman sebagai wujud telah tercapainya bahan pokok dan usaha dapat meminimalisir kekurangan pasokan air ke warga.

\section{(METODE)}

Dampak hasil luaran yang telah diuraikan sebelumnya bagi kelompok tani dan masyarakat sebagai berikut:

1) Pembuatan tandon air untuk memenuhi kebutuhan air untuk warga dusun Gutean.

2) Pembuatan instalasi air bersih (pipanisasi) dari tandon ke masjid.

3) Memberikan pelatihan dalam pengelolaan air bersih, terutama dalam proses pembagian air dan pemeliharan instalasi air dalam hal kebocoran pipa serta kerusakan pompa air.

4) Memberikan penyuluhan untuk menciptakan kerjasama atau kemitraan antara pengurus dengan masyarakat sehingga terbentuk komunikasi yang efektif sehingga program kerja bisa berjalan dengan baik.

Merencanakan dan membuat instalasi air untuk memenuhi kebutuhan pasokan air bersih ke warga.

\section{METODE PELAKSANAAN}

\section{Tempat dan Waktu Kegiatan}

Program pengabdian pada masyarakat ini dilaksanakan di Dusun Gutean Desa Karangrejo Kecamatan Purwosari Kabupaten Pasuruan Jawa Timur. Program pengabdian ini dilakukan selama 8 bulan. 


\section{Pelaksanaan Kegiatan}

Adapun dalam pelaksanaannya kegiatan IbM ini meliputi pembuatan tandon air, pembuatan instalasi air bersih, penyuluhan dan evaluasi untuk melihat efektivitas program dalam sosialisasi. Tahapan-tahapan pelaksanaan IbM ini dijelaskan sebagai berikut :

1. Sosialisasi awal dengan warga dusun Gutean untuk menjelaskan pelaksanaan program IbM ini. Dalam sosialisasi ini dilakukan untuk mensinkronkan tujuan dari program IbM dengan apa yang menjadi permasalahan warga dusun Gutean terutama dalam hal kebutuhan air bersih. Pada kegiatan ini peneliti dan warga merencanakan apa yang harus dilakukan dalam memenuhi kebutuhan air bersih. Dalam perencanaan ini diperoleh kesepakatan untuk membuat tandon air secara mandiri, artinya tandon air dibuat terpisah dengan tandon yang lama seperti pada gambar 1. Dengan dibuatnya tandon air juga membutuhkan instalasi air bersih dari sumber air ke tendon air. Untuk tendon air direncanakan dibuat didalam tanah.

2. Survey lapangan untuk menentukan posisi tandon air dan perletakan pipa yang akan dipasang dari sumber air ke tandon air. Dimana untuk pemasangan pipa akan diletakkan menyusuri daerah persawahan dan pemukiman penduduk.

3. Kegiatan berikutnya yaitu dengan pembuatan tandon air, dimana pekerjaan ini dilakukan oleh warga secara bergotong royong dan dibantu oleh beberapa tukang, karena pekerjaan ini membutuhkan oleh tenaga yang ahli dalam pembuatan tandon. Beberapa pekerjaan yang dilakukan antara lain :

a. Penggalian tanah untuk tandon

b. Pembuatan rangka besi untuk tendon

c. Pengecoran beton untuk tendon

d. Pemasangan instalasi air ke pompa air

e. Pemasangan tutup tendon

f. Pemasangan instalasi air berih dari sumber air ke tandon 


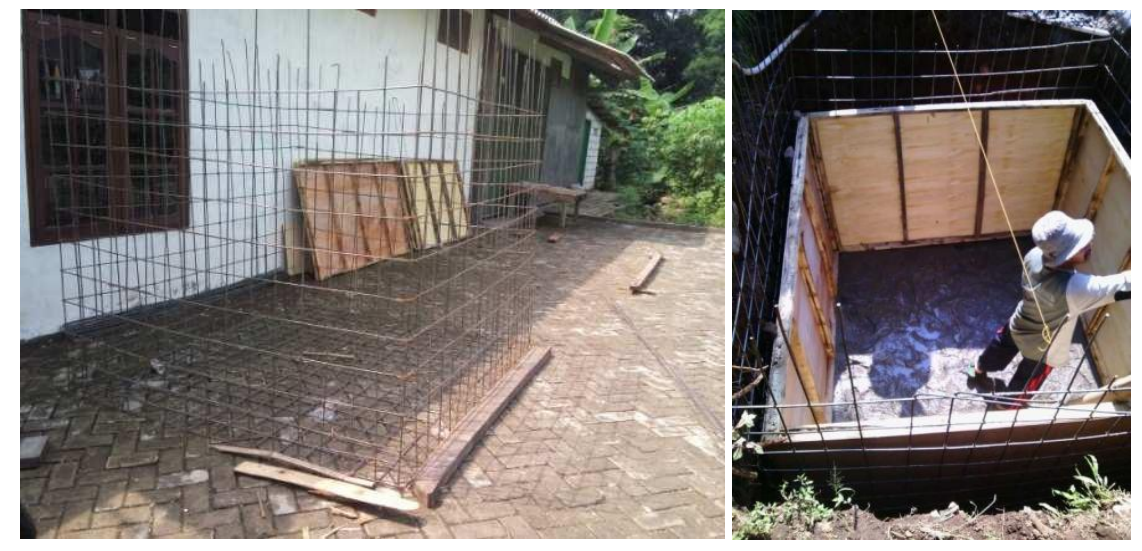

Gambar 1. Pemasangan bekisting dan persiapan pengecoran
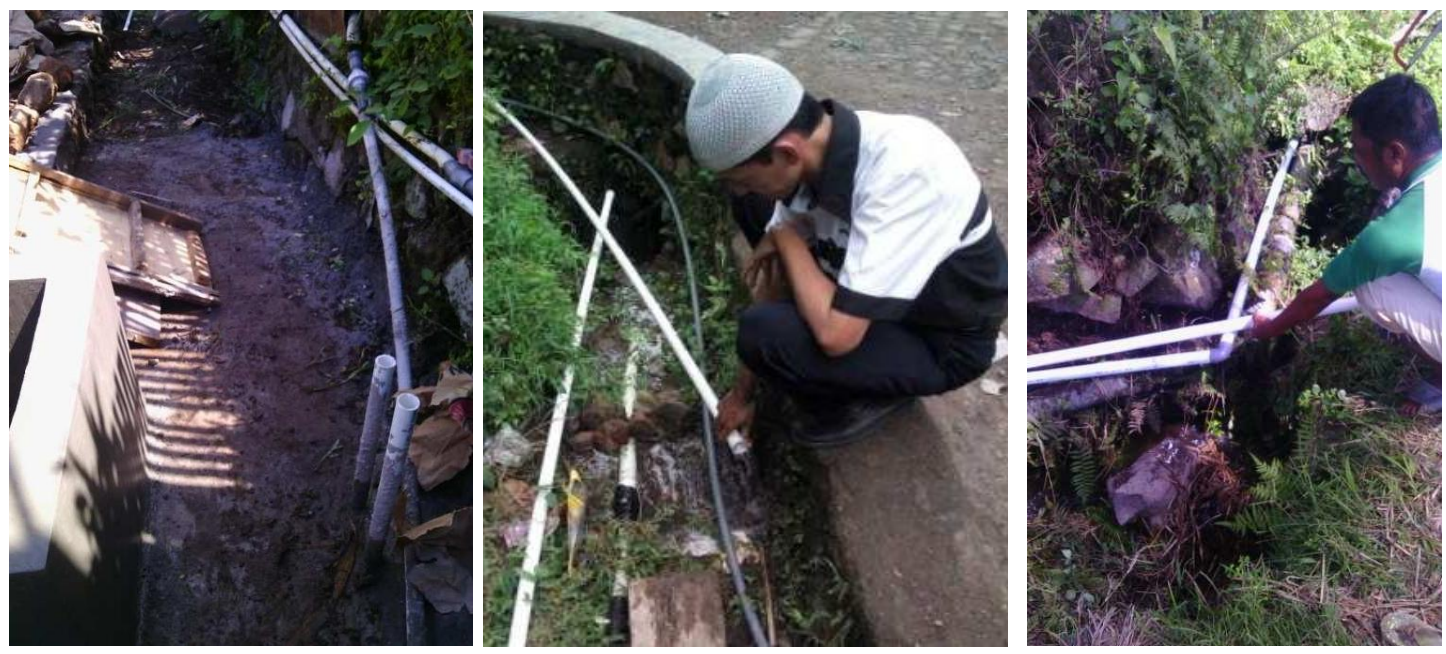

Gambar 2. Instalasi air ke pompa air
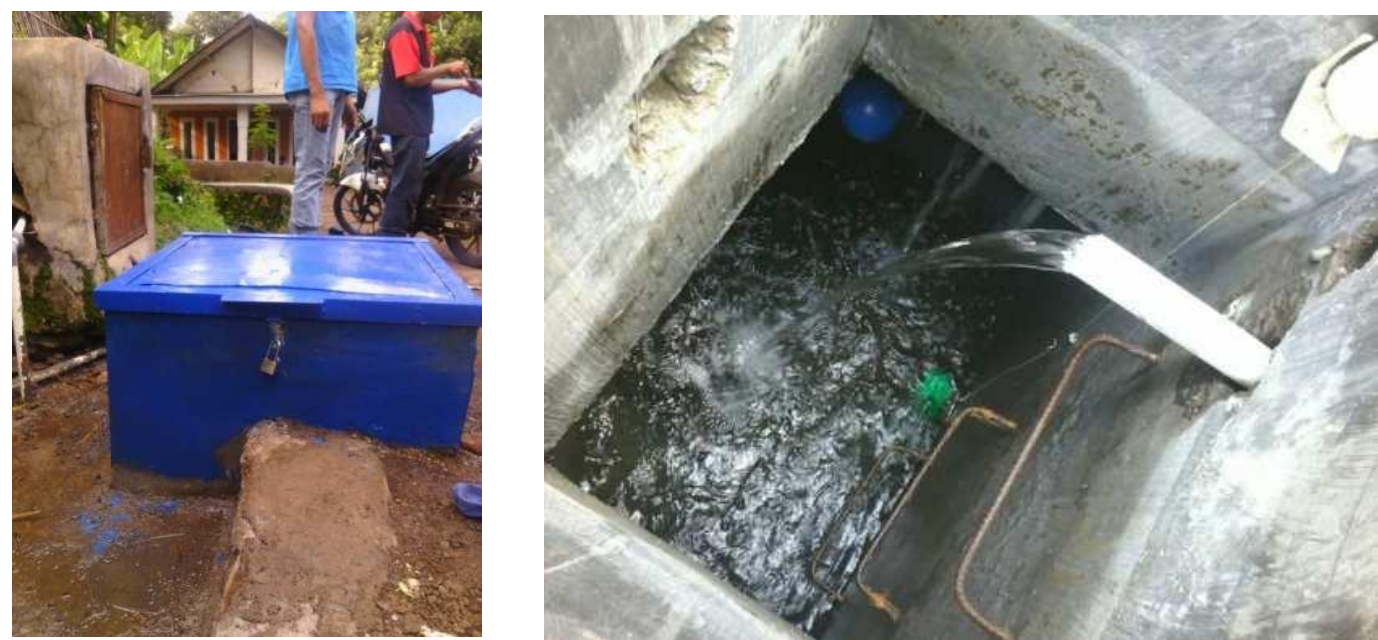

Gambar 3. Tutup Tandon dan Pemasangan pipa instalasi air

Volume 1, Number 1, Mei 2017|7

Pengolahan Sumber Daya Air untuk Meningkatkan Kesejahteraan Masyarakat di Desa Karangrejo Dusun Gutean Kecamatan Purwosari Kabupaten Pasuruan

Mochamad Mas'ud, Rukma Nur Patriya, Januar Sasongko 


\section{Sosialisasi dengan selesainya}

pekerjaan pembuatan tandon. Didalam kegiatan ini peneliti menyampaikan dengan hasil yang telah dilaksanakan, serta melakukan pelatihan dan penyuluhan pengelolaan distribusi air agar supaya ada kerjasama antara pengurus dalam hal ini kelompok POSDAYA dan warga setempat. Hal ini dilakukan supaya dapat mengurangi gesekan sosial antar warga. Serta penyuluhan pentingnya pola hidup sehat. Dengan tingkat pendidikan yang rendah diperlukan penyuluhan yang intensif dengan pola pendekatan yang baik. Penyuluhan ini memerlukan peran aktif dari peserta agar tujuan dari penyuluhan ini mengena. Didalam sosialisasi ini juga dilakukan pelatihan leadership (kepemimpinan) bagi pengurus. Transfer ilmu pengetahuan ini sebagai upaya untuk meningkatkan pengetahuan dan ketrampilan sumberdaya manusia pada kelompok usaha kedua mitra dalam hal manajerial ketua kelompok dalam mengelola usaha, pembagian tugas dan pemahaman terhadap tugas dan fungsi tiap anggota kelompok sehingga produktifitas setiap anggota akan meningkat. Dengan meningkatnya produktifitas setiap anggota kelompok pada akhirnya akan tercipta kemandirian kelompok usaha itu sendiri
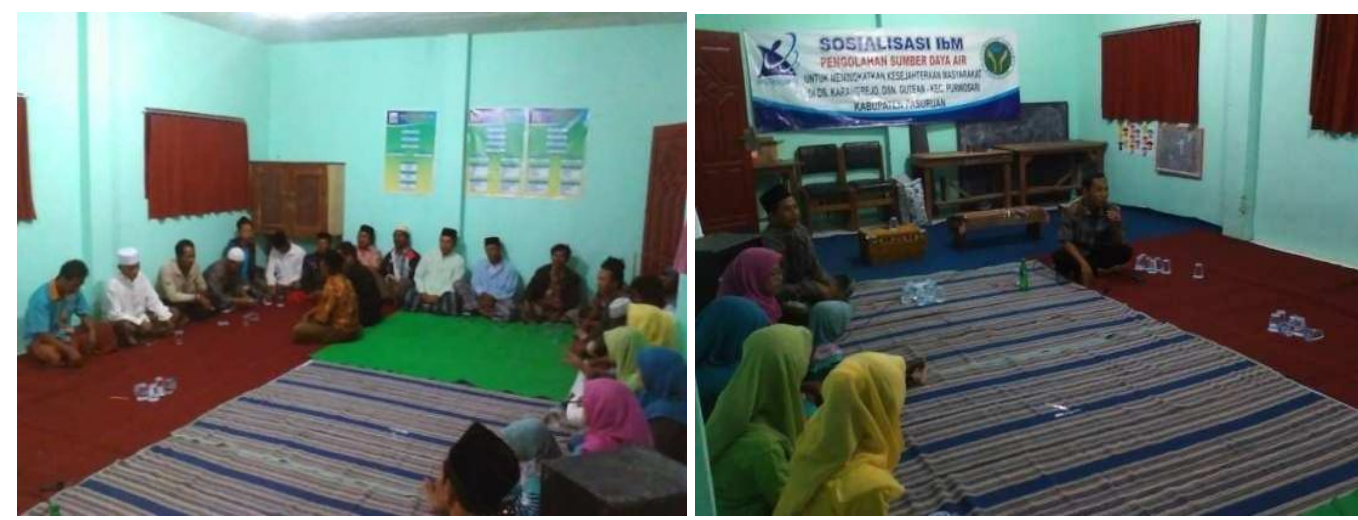

Gambar 4. Proses sosialisasi dan penyuluhan

5. Pemasangan instalasi air dan pompa untuk masjid untk memenuhi kebutuhan air bagi keperluan masjid. Kegiatan ini meliputi pembuatan rumah pompa, pemasangan instalasi air bersih ke masjid serta pemasangan pompa air. 


\section{KELAYAKAN PERGURUAN TINGGI}

Lembaga Penelitian dan Pengabdian kepada Masyarakat Universitas Yudharta Pasuruan (LPPM UYP) sesuai misi dan visinya mempunyai tugas melakukan koordinasi dan melaksanakan pengelolaan kelembagaan dalam mengembangkan program penelitian dan pengabdian kepada masyarakat yang dilaksanakan oleh sivitas akademika Universitas Yudharta Pasuruan mulai dari fakultas, program studi hingga perpustakaan. PPM UYP pada tahun 2015 telah menyusun road map penelitian institusi yaitu penelitian dan pengabdian masyarakat dengan mendukung dan pemberdayaan sumberdaya lokal yang pluralis dan multikutural untuk kemajuan ilmu dan teknologi. Road Map penelitian ini merujuk pada visi misi institusi yaitu menjadikan universitas sebagai wahana pengembangan ilmu pengetahuan dan teknologi yang berlandaskan tata nilai kehidupan masyarakat religius pluralistik untuk mengupayakan sarjana profesional dan bermartabat.

Untuk mewujudkan visi misinya LPPM UYP telah melakukan beberapa program kerja yang antara lain : Mengadakan worksohop dan pelatihan penyusunan proposal penelitian dan pengabdian masyarakat dengan narasumber dari dosen UYP sendiri dan beberapa universitas seperti UNIBRAW, UNEJ, UNPAD, IPB dan ITS Menjalin kerjasama dengan instansi dan lembaga pemerintah dalam bidang penelitian dan pengabdian masyarakat, contoh : LIPI Purwodadi Pasuruan, Balitkabi, PU Kota dan Kab Pasuruan, PEMDA Kabupaten dan Kota Pasuruan

Menjalin kerjasana dengan perusahaan industri di Kabupaten Pasuruan dalam bidang penelitian dan pengabdian masyarakat, contoh : INDOLAKTO, DANONE, SORIM, BOSTO, PILAR PANCA, DUTA BETON, IWINS USAID PANDAAN DAN MANDIRI INVESTAMA SEJATI.

Menjalin kerjasama dengan perguruan tinggi negeri dan swasta di Jawa Timur. Berpartisipasi dalam pemberdayaan masyarakat dengan menjadi fasilitator dan pendamping UKM, POSDAYA, Organisasi Masyarakat di Kabupaten Pasuruan.

Memfasilitasi dosen-dosen Universitas Yudharta Pasuruan dalam penelitian dan pengabdian dengan instansi/lembaga yang dibutuhkan untuk menunjang pelaksanaan kegiatan tersebut Pada tahun 2015 LPPM UYP didalam program kerjanya khususnya pada saat KKN 2014 bekerjasama dengan UIN Malang mengambil program 
pemberdayaan masyarakat dengan wujud membentuk Pos Pemberdayaan Masyarakat. KKN tersebut dilaksanakan di 3 kecamatan terdekat dengan lokasi kampus antara lain Purwosari, Purwodadi dan Tutur. Dalam kegiatan KKN tersebut telah berhasil membentuk 17 POSDAYA berbasis masjid yang salah satunya adalah POSDAYA Al- Huda di dusun Gutean desa karangrejo kecamatan Purwosari Pasuruan. Dalam kegiatan yang berkelanjutan LPPM UYP menggunakan pendekatan pendampingan terhadap POSDAYA tersebut.

\section{HASIL YANG DICAPAI}

Kegiatan pengabdian kepada masyarakat ini diperoleh dari hasil KKN mahasiswa pada tahun 2014. Dari keinginan warga Dusun Gutean Desa Karangrejo Kecamatan Purwosari Kabupaten Pasuruan yang disampaikan mahasiswa KKN yaitu ketersediaannya kebutuhan air bersih untuk kesehariannya dan juga untuk wirausaha yang dilakukan oleh warga dusun tersebut.

Kegiatan ini dilaksanakan dengan pembuatan tandon air bersih dan instalasi air bersih dari sumber ke tandon penampung air bersih. Dimana dari tandon penampung tersebut dialirkan ke seluruh warga dusun Gutean khususnya yang berada di wilayah RT.03, RT.04 dan RT.06. Serta pembuatan instalasi air bersih yang ditujukan ke masjid dusun Gutean.

Selain kegiatan fisik diatas juga dilakukan kegiatan berupa penyuluhan dan pelatihan. Pelaksanaan penyuluhan ini terkait dengan bagaimana cara pengelolaan dalam melakukan pendistribusian air bersih ke warga, agar supaya tidak terjadi gesekan sosial antar warga seperti waktu sebelumnya. Penyuluhan ini memberikan kesadaran warga akan kebutuhan air bersih yang harus dapat dirasakan secara bersama antar warga dan tidak berdasarkan kepentingan perseorangan atau wilayah RT.

Sedangkan didalam pelaksanaan pelatihan dalam hal ini tim pelaksana melakukan transfer ilmu pengetahuan untuk bagaimana cara tata kelola dalam pendistribusian air bersih serta cara pemeliharaan instalasi air bersih dari sumber air sampai ke warga. Adapun yang dapat dilakukan oleh warga dan pengurus mitra antara lain:

1. Dengan membentuk pengurusan baru dengan koordinator per wilayah RT.

2. Mengatur waktu pendistribusian air bersih perwilayah. 
3. Mengatur jadwal kontrol dalam proses pemeliharaan instalasi air bersih serta pompa air.

4. Menyusun besar konstribusi yang harus dikumpulkan dari warga untuk digunakan dalam proses pemeliharaan. Dalam hal ini telah menjadi kesepakatan antar warga untuk dapat memberikan konstribusi sebesar Rp.5000/bulan/KK

\section{RENCANA}

\section{TAHAPAN BERIKUTNYA}

Setelah tercapainya target dari pelaksanaan ini, maka tim pelaksana juga mempunyai rencana tahapan berikutnya yaitu :

1. Pendampingan berkelanjutan Kegiatan ini dilakukan dengan cara membuka seluas-luasnya apabila mitra ingin berkonsultasi tentang pengelolaan air bersih yang baik, terutama dalam masalah pemeliharaan instalasi. Serta melakukan kerjasama dengan pemerintah daerah untuk bisa memberikan akan kebutuhan air bersih untuk wilayah lain dari dusun Gutean, yang seperti diketahui di atas bahwa penyediaan air bersih ini masih dirasakan oleh warga yang berada di RT.03, RT.04 dan RT.06 saja.

2. Mengajukan proposal baru Proposal baru ini dibuat untuk dapat memberikan pengetahuan dalam peningkatan taraf hidup warga dusun Gutean. Terutama dalam pembinaan dan perluasan usaha yang ada di dusun Gutean.

\section{KESIMPULAN DAN SARAN}

\section{Kesimpulan}

Berdasarkan hasil yang dicapai,maka dapat disimpulkan sebagai berikut:

1. Telah terlaksananya pembuatan tandon dan instalasi air bersih untuk memenuh kebutuhan air bersih di Dusun Gutean Desa Karangrejo Kecamatan Purwosari Kabupaten Pasuruan.

2. Seluruh warga Dusun Gutean Desa Karangrejo Kecamatan Purwosari Kabupaten Pasuruan khususnya RT.03, RT.04 dan RT.06 telah merasa tercukupi dengan adanya pembuatan tandon dan instalasi air bersih.

Volume 1, Number 1, Mei 2017| 11 
3. Dari proses penyuluhan dan pelatihan diperoleh kepengurusan baru untuk masalah pendistribusian air bersih, dengan dibentuknya beberapa koordinator untuk mengkoordinasikan warga perwilayah. Serta mendapatkan transfer ilmu pengetahuan dalam proses pengelolaan dan pemeliharaan instalasi air bersih.

\section{Saran}

1. Perlu adanya tindak lanjut dari Kepala Desa Karangrejo Kecamatan Purwosari Kabupaten Pasuruan untuk menindaklanjuti kegiatan yang sudah terlaksana ini untuk bisa dikembangkan ke wilayah lain, karena masih banyak warga yang masih kekurangan akan kebutuhan air bersih.

2. Perlu adanya pendampingan secara intensif agar supaya terbentuknya suatu pengelolaan air bersih yang baik. 


\section{ENGAGEMENT}

Jurnal Pengabdian Kepada Masyarakat ISSN : 2579-8375 (Print) ISSN : 2579-8391 (Online)
This work is licensed under a Creative Commons Attribution-ShareAlike 4.0 International License. CC BY SA

\section{DAFTAR PUSTAKA}

Anonim. 2002. Pedoman/Petunjuk Pelaksanaan Teknik dan Manual. Jakarta.

Lufira, Rahmah Dara, Suharjono, Suwanto Marsudi, 2012, Optimasi Dan Simulasi Sistem Penyediaan Jaringan Air Bersib Di Kecamatan Kademangan Kabupaten Blitar, Jurnal Teknik Pengairan Vol.3. No.1, Universitas Brawijaya, Malang

Nelwan, Fenny, E. M. Wuisan, L.

Tanudjaja, 2013, Perencanaan Jaringan Air Bersih Desa Kima Bajo Kecamatan Wori, Universitas Sam Ratulangi, Manado

Triatmadja, Radianta, 2007. Sistem Penyediaan Air Minum Perpipaan, Yogyakarta.

Triatmodjo, Bambang, 2008.

Hidraulika II, Beta Offset, Yogyakarta 